\title{
A proposed mechanism for enhanced water-conservation in egg clutches of the Mexican Kingsnake, Lampropeltis mexicana (Serpentes: Colubridae)
}

\author{
Richard S. Phillips, Andrew J. Jajack, and Jay A. Yoder \\ Department of Biology, Wittenberg University, Springfield, Ohio 45501, USA. E-mail: jyoder@wittenberg.edu.
}

\begin{abstract}
A proposed mechanism for enhanced water-conservation in egg clutches of the Mexican Kingsnake, Lampropeltis mexicana (Serpentes: Colubridae). Laying eggs on a wet substrate minimizes water stress for flexible-shelled reptile eggs because they absorb water through the permeable shell. This water gain contributes to reduced water-loss in aggregated eggs. This water-conserving feature is demonstrated in eggs of Lampropeltis mexicana in a water-balance experiment investigating both naturally laid clutches and eggs in arranged clusters. Water-loss rates of eggs decrease as more eggs are added to the aggregation, with a threshold at approximately 15 eggs. There is no further reduction in water-loss rate for eggs in an aggregation of 20, which exceeds the typical maximum for natural clutch size in this species. Blowing dry air over the egg clutch causes this waterconserving feature to disappear, but it re-appears when the air is still (air current turned off). This is the first time that an increase in water-vapor pressure in an aggregation of eggs has been demonstrated experimentally; the results suggest that laying aggregations of eggs may benefit development through moisture conservation.
\end{abstract}

Keywords: moisture requirement, snakes, water-balance.

\footnotetext{
Resumo

Proposta de um mecanismo para o aumento da conservação de água em desovas da serpente Lampropeltis mexicana (Serpentes: Colubridae). A postura de ovos em um substrato úmido minimiza o estresse hídrico de ovos de répteis com casca coriácea, pois permite que absorvam água através da casca permeável. Esse ganho de água contribui para a redução da perda de água em ovos agregados. Demostramos aqui essa característica de conservação de água em ovos da serpente
}

Received 21 August 2014.

Accepted 1 December 2014.

Distributed December 2014. 
Lampropeltis mexicana em um experimento de balanco hídrico investigando tanto desovas naturais como ovos arranjados experimentalmente em grupos. As taxas de perda de água dos ovos continuam a diminuir à medida que mais ovos são adicionados ao agregado, com um limiar de aproximadamente 15 ovos. Não há redução adicional da taxa de perda de água em um agregado de 20 ovos, número maior que o tamanho típico máximo da desova natural dessa espécie. Correntes de ar seco dirigidas sobre a desova provocam o desaparecimento dessa característica de conservação de água, mas esta reaparece quando o ar está imóvel (desligando-se a corrente de ar). Essa é a primeira vez que um aumento na pressão de vapor de água em um agregado de ovos é demonstrado experimentalmente; os resultados sugerem que a postura de ovos agregados pode beneficiar o desenvolvimento por meio da conservação de umidade.

Palavras-chave: balanço hídrico, requisito de umidade, serpentes.

\section{Introduction}

Flexible squamate eggshells offer little resistance to water-loss and feature a high permeability to water (Andrews 2012, Sartori et al. 2012). Moreover, the small size of the eggs exacerbates water-loss owing to surface area to volume properties (Díaz-Paniagua et al. 1996). Because reptile eggs are cleidoic systems, they cannot replenish lost water stores by drinking or feeding. Obviously, moisture is important to maintain adequate levels of body water (i.e., water-balance) for egg viability, proper development, and hatching in snakes, lizards, and tortoises (Plummer and Snell 1988, Keller et al. 1997, Díaz-Paniagua and Cuadrado 2003, Marco et al. 2004, Díaz-Paniagua et al. 1997, 2006, Stahlschmidt et al. 2008, Andrews 2012). Moisture loss can also have negative effects on hatchling growth and condition (Miller et al. 1987, Keller et al. 1997, Marco et al. 2004).

Given potential costs of moisture loss, females are behaviorally adapted to seek sheltered, moisture-rich refuges under leaf litter, rocks, the soil surface, and fallen logs for laying their eggs (Conant and Collins 1998). Contact with wet substrates and the high permeability of flexible eggshells permit water to be absorbed and delivered directly to the egg by diffusion (Marco et al. 2004, Andrews 2012), because $1.00 a_{\mathrm{w}}$ (substrate) $>0.99 a_{\mathrm{w}}$ (body water)
(Wharton 1985). Egg aggregation decreases water-loss rates in lizard eggs that are incubated on moist substrates (Marco et al. 2004, Marco and Díaz-Paniagua 2008), thereby enhancing water-conservation and survival during potentially long incubation periods.

Lampropeltis mexicana, the subject of this study, refers to a complex of Mexican kingsnakes, the exact taxonomic status of which is ambiguous (Bryson et al. 2007). These snakes occupy a variety of semi-montane and montane habitats in the northern Sierra Madre Oriental in Mexico at altitudes between 2000 and $3500 \mathrm{~m}$ in mesic subtropical forests and xeric scrublands (Gartska 1982, Conant and Collins 1998). Little is known about the life history in nature, although $L$. mexicana is increasingly popular among herpetoculturists (Lassiter 2012). Captive adults range from $0.75-0.90 \mathrm{~m}$ in length, and females lay 5-19 eggs, with an average of nine (Figure 1). Kingsnake rearing protocols call for moistened sphagnum moss for oviposition and incubation of the eggs until hatching (Figure 1). Depending on the incubation temperature, these eggs hatch in about 60 days (pers. obs.). Captive females can lay a second clutch; however, this has not been observed in the wild (Lassiter 2012). An additional component of moisture regulation that characterizes clutch grouping in egg clutches of a captive Mexican Kingsnake, L. mexicana, is described herein. 


\section{Materials and Methods}

Our colonies of Lampropeltis mexicana (Sierra Herps, Clovis, CA, USA) are about 5 years old, and eggs were from long-term captivebred snakes. The snakes are kept on woodchips (Aspen Snake bedding, Zoo Med Laboratories, San Luis Obispo, CA, USA) in plexiglass cages $(91 \times 61 \times 29 \mathrm{~cm}, 1 \times \mathrm{w} \times \mathrm{h}$; Boaphile Plastics, Cannon Falls, MN, USA), $0.30 \pm 0.03 a_{\mathrm{v}}, 29 \pm$ $1{ }^{\circ} \mathrm{C}, 12 \mathrm{~h}: 12 \mathrm{~h} \mathrm{~L}: \mathrm{D}$ in an environmental chamber (Fisher Scientific, Pittsburg, PA, USA; thermal probe; $\mathrm{SD} \leq \pm 0.5^{\circ} \mathrm{C}$; Thomas Scientific, Philadelphia, PA, USA). Snakes are fed two adult mice per week (thawed, laboratory-reared adult mice, Mus musculus; Big Cheese Rodent Factory, Fort Worth, TX, USA) and tap water ad libitum (without antibiotics). The eggs were approximately 2 wk old. We wore sterile, powder-free gloves (Microflex Co., Reno, NV, USA) and used felt-tipped soft forceps (Fisher) to handle and separate the eggs. Eggs were selected from randomized clutches from multiple snakes. We examined the eggs at $10 \times$ to determine that the chorion was not collapsed and that there was no evidence of dehydration, fluid leakage, or damage from handling. The temperature was maintained at $25^{\circ} \mathrm{C}$, the standard for water-balance studies (Hadley 1994) and within the range of temperatures experienced by these snakes in the wild (Conant and Collins 1998).

We determined water-balance characteristics with Wharton's (1985) gravimetric methods that yield identical results with ${ }^{3} \mathrm{HOH}$ tracers (Knülle and Devine 1972). Eggs were weighed individually, without enclosure, in less than $1 \mathrm{~min}$ with a Cahn electrobalance (precision of $\mathrm{SD} \pm$ $0.2 \mu \mathrm{g}$, accuracy of $\pm 6 \mu \mathrm{g}$ at $1 \mathrm{mg}$; Ventron Co., Cerritos, CA, USA). Individual eggs within aggregations were marked with a spot of nontoxic paint (Pactra, Rockford, IL, USA) applied by a single bristle of a soft camel-hair brush (Atlas Brush, Cleveland, OH, USA). Paint had no effect on mass changes (data not shown). An isolated egg acted as the control. To ensure

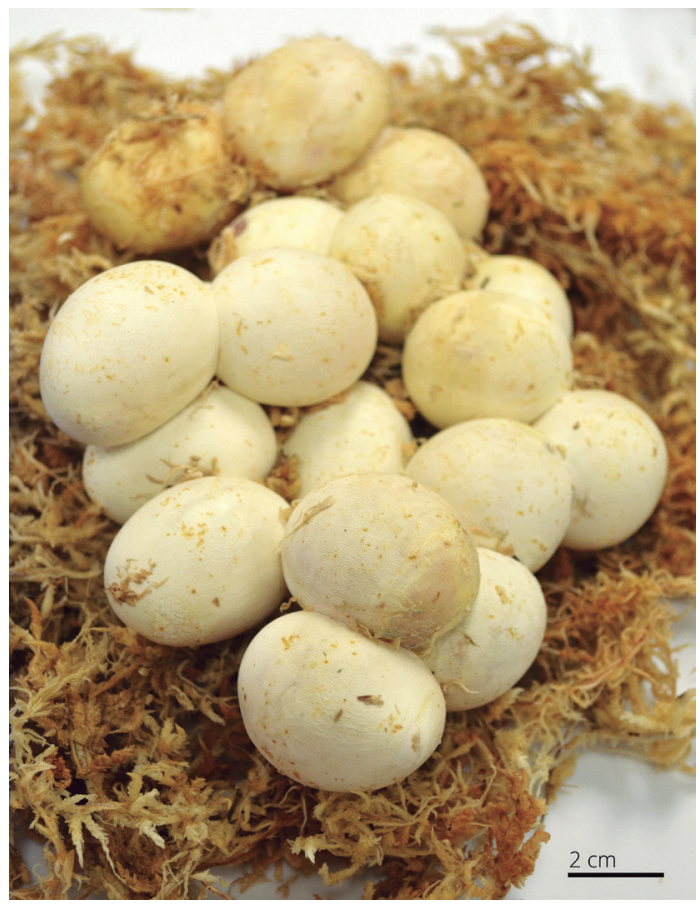

Figure 1. Naturally laid clutch of eggs from L. mexicana, on sphagnum moss. Photo: R. S. Phillips.

that changes in egg mass reflected changes in body-water levels, each egg was pre-desiccated by $4-6 \%$ at $0.33 a_{\mathrm{v}}$ (sat. $\mathrm{MgCl}_{2}$; Winston and Bates 1960) (Arlian and Eckstrand 1975). After an experiment, dry mass $(d)$ was determined by placing eggs in a $90 \pm 2.0^{\circ} \mathrm{C}$ oven (Blue $\mathrm{M}$ Electric Co., Chicago, IL, USA). Dry mass $(d)$ was subtracted from mass measurements for conversion to the water mass $(m): m=f$ - $d$, where $f$ is initial, fresh mass, and percentage $m=$ $100(f-d) / f$ (Wharton 1985).

Water-loss is exponential only at $0.00 a_{\mathrm{v}}$ $\left(\mathrm{CaSO}_{4}\right.$; Drierite; W. A. Hammond Drierite Co., Xenia, OH, USA; Toolson 1978; Thomas hygrometer $\mathrm{SD} \leq \pm 0.03 a_{\mathrm{v}}$ ). This value was selected to determine water-loss rate (chorionic + respiratory water-loss) by applying the kinetic model equation, $m_{t}=m_{0} \mathrm{e}^{-k t}$, where $m_{t}$ is the water mass at any time $t, m_{0}$ is the initial water mass, 
and $k$ is the percentage mass lost per unit hour. (Wharton 1985). Rather than placing the eggs on sphagnum moss (Figure 1), they were placed on pre-dried, baked perforated porcelain plates and in total dryness at $0.00 a_{\mathrm{v}}$ within 3-L desiccators. There is no adsorbed water by passive chemisorption or physical adsorption-i.e., $\Psi=$ $-\infty \mathrm{MPa}$. The experiments were repeated using $0.00 a_{\mathrm{v}}$ currents at $50 \mathrm{ml} / \mathrm{min}$ (Wharton and Knülle 1966; flow meter, Rochester Gauges, Dallas, TX, USA) from a laboratory source of compressed air, passed through a Drierite-packed column $(15 \times 3 \mathrm{~cm}, 1 \times \mathrm{w}$; Fisher $)$ that was connected by $1.0-\mathrm{cm}$ Tygon tubing (Fisher) to the desiccator.

Data are the mean $\pm \mathrm{SE}$, representing total $N$ $=15$ (3 replicates of 5 eggs each). Data were compared by an analysis of covariance (ANCOVA), following a logit transformation for percentage data (Warton and Hui 2011). Test for the equality of slopes of several regressions (Sokal and Rohlf 2012) was used to compare characteristics derived from regression lines. Statistical software was SPSS 14.0 for Windows (IBM, Armonk, NY, USA), Microsoft Excel (Redmond, WA, USA), and Minitab (Chicago, IL, USA).

\section{Results}

Eggs were similar in size, shape, and bodywater content (Table 1). Water mass correlated positively with dry mass: $R \geq 0.91,0.89$ and 0.93 for eggs in clutch sizes of six, eight, and 17 $(p<0.001$; Table 1), $m / d=2.6,2.2$, and 2.4, respectively. Similarly, water mass of eggs manually aggregated into groups of $1,5,10,15$, and 20 was a positive correlate of dry mass $(R$ $\geq 0.88,0.92,0.94,0.89$, and 0.90 , respectively; $p<0.001$ ) with corresponding $2.3,2.4,2.2,2.6$, and $2.5 \mathrm{~m} / \mathrm{d}$. Water-loss rate decreased with increasing aggregation size in natural and arranged groups (Table 1). An equilibrium point apparently occurs with higher egg densities when the clutch size numbers about 15 eggs. Because of similarity in egg size and an exchangeable water pool (Table 1), effects reflecting surface area to volume properties are negligible with regard to the water-loss rate of individual eggs. Thus, differences in water-loss suppression are attributed to an effect of the aggregation.

In moving air, water-loss is approximately twice as fast in individual eggs in an aggregation of 10 compared to still air $(0.114 \pm 0.005 \% / \mathrm{h}$ vs. $0.052 \pm 0.007 \% / \mathrm{h}$, respectively; Figure $2 ; p>$ $0.05)$. In moving air, water-loss of individuals in groups does not differ from that of isolated eggs $(0.114 \pm 0.005 \% / \mathrm{h}$ vs. $0.128 \pm 0.010 \% / \mathrm{h}$, respectively; Figure $2 ; p>0.05$ ). When turning off the air current, water-loss rate of individual eggs in an aggregation of 10 becomes lower $(0.061 \pm 0.010 \% / \mathrm{h} ; p<0.05$; Figure 2$)$. Thus, the characteristic low water-loss rate for eggs in an aggregation of 10 is restored through a cycle from still air (low water-loss rate) to moving air (high water-loss rate) and return to still air (low water-loss rate) applied to the same egg.

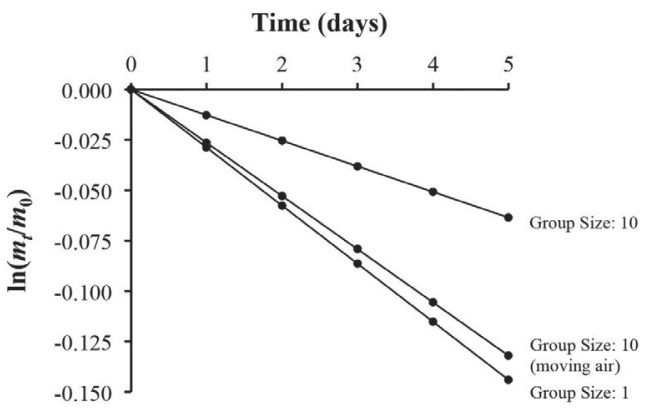

Figure 2. Impact of dry air currents on water-loss $\left(25^{\circ} \mathrm{C}\right.$, $0.00 a_{v}$ ) of eggs of L. mexicana. Slope of the regression line is the water-loss rate, where $m_{t}$ is water mass at any time $t$, and $m_{0}$ is initial water mass. Each point is the mean of 15 eggs $( \pm \mathrm{SE} \leq 0.012)$.

\section{Discussion}

Our data support those of Marco et al. (2004) and Marco and Díaz-Paniagua (2008) on lizard eggs, thereby reinforcing the strong association 
Table 1. Water-balance characteristics of eggs of Lampropeltis mexicana. These data are from randomly chosen eggs from within a clutch. Data (the mean \pm SE of 15 eggs) followed by the same superscript letter within a column are not significantly different $(p>0.05)$.

\begin{tabular}{|c|c|c|c|c|c|}
\hline \multirow[b]{2}{*}{ Treatment } & \multicolumn{3}{|c|}{ Mass (g) of individual eggs monitored: } & \multirow{2}{*}{$\begin{array}{c}\text { Water content } \\
(\%)\end{array}$} & \multirow{2}{*}{$\begin{array}{c}\text { Water-loss rate } \\
(\% / \mathrm{h})\end{array}$} \\
\hline & Initial, $f$ & Dry, $d$ & Water, $m$ & & \\
\hline \multicolumn{6}{|l|}{ Laid naturally } \\
\hline \multicolumn{6}{|c|}{ Clutch size } \\
\hline 6 & $12.04 \pm 0.24^{\mathrm{a}}$ & $3.39 \pm 0.13^{\mathrm{a}}$ & $8.65 \pm 0.10^{\mathrm{a}}$ & $71.84 \pm 2.3^{\mathrm{a}}$ & $0.109 \pm 0.007^{a}$ \\
\hline 8 & $12.32 \pm 0.14^{\mathrm{a}}$ & $3.85 \pm 0.09^{\mathrm{a}}$ & $8.47 \pm 0.13^{a}$ & $68.75 \pm 2.7^{\mathrm{a}}$ & $0.088 \pm 0.011^{\mathrm{a}}$ \\
\hline 17 & $11.38 \pm 0.20^{\mathrm{a}}$ & $3.49 \pm 0.15^{\mathrm{a}}$ & $8.34 \pm 0.09^{a}$ & $70.50 \pm 1.8^{\mathrm{a}}$ & $0.043 \pm 0.009^{b}$ \\
\hline \multicolumn{6}{|c|}{ Clustered manually } \\
\hline \multicolumn{6}{|c|}{ Group size } \\
\hline 1 & $12.41 \pm 0.18^{\mathrm{a}}$ & $3.78 \pm 0.11^{\mathrm{a}}$ & $8.63 \pm 0.06^{\mathrm{a}}$ & $69.54 \pm 1.9^{\mathrm{a}}$ & $0.128 \pm 0.010^{c}$ \\
\hline 5 & $11.70 \pm 0.11^{\mathrm{a}}$ & $3.46 \pm 0.12^{\mathrm{a}}$ & $8.24 \pm 0.08^{\mathrm{a}}$ & $70.42 \pm 1.9^{\mathrm{a}}$ & $0.097 \pm 0.005^{\mathrm{a}}$ \\
\hline 10 & $11.44 \pm 0.18^{\mathrm{a}}$ & $3.56 \pm 0.07^{a}$ & $7.88 \pm 0.08^{\mathrm{a}}$ & $68.88 \pm 2.3^{\mathrm{a}}$ & $0.052 \pm 0.007^{d}$ \\
\hline 15 & $11.16 \pm 0.19^{\mathrm{a}}$ & $3.12 \pm 0.08^{\mathrm{a}}$ & $8.04 \pm 0.05^{\mathrm{a}}$ & $72.04 \pm 1.7^{\mathrm{a}}$ & $0.039 \pm 0.009^{b}$ \\
\hline 20 & $12.24 \pm 0.22^{\mathrm{a}}$ & $3.50 \pm 0.13^{\mathrm{a}}$ & $8.74 \pm 0.10^{\mathrm{a}}$ & $71.40 \pm 2.1^{\mathrm{a}}$ & $0.044 \pm 0.005^{b}$ \\
\hline
\end{tabular}

between flexible-shelled squamate eggs and aggregation as mechanisms to control water stress. The eggs in Marco et al. (2004) and Marco and Díaz-Paniagua's (2008) studies were in direct contact with a wet substrate; thus, water potential $(\Psi)$ was used to reflect water movement from the substrate into the egg. The water potentials (-0.15 $\mathrm{MPa}$ to $-1.95 \mathrm{MPa}$ ) are close to saturation and approach $1.00 a_{\mathrm{w}}(=0.00 \mathrm{MPa}$; conversions by Liu et al. 2012). We show this enhanced water-conservation effect in eggs at $\Psi=-\infty \mathrm{MPa}\left(=0.00 a_{\mathrm{v}}\right.$; Liu et al. 2012), and by examining laid clutches, in addition to manually constructed clusters, demonstrated that this water-conservation effect is a natural phenomenon. This water-conservation by aggregation disappears in moving dry air, and re-appears in still air. Given the relationship between inward (sorption, $m_{\mathrm{S}}$ ) and outward water fluxes (transpiration, $\left.m_{\mathrm{T}}\right)$ and water-balance $(\Delta m=0$; Wharton 1985), it seems likely that the lower water-loss rate in aggregated eggs is a result of water gains masking, at least in part, the large body-water losses.

Clutches of snake eggs might suppress the water-loss rate of individuals in the aggregation by acting as a "superorganism" with regard to water-balance through surface area to volume properties and minimizing the evaporative surface. Such a surface area-to-volume approach can be inferred from the works of Díaz-Paniagua and Cuadrado (2003) on lizard eggs and Díaz-Paniagua et al. (1996) on tortoise eggs. It is also possible that suppression of the egg metabolism and slowing development (Andrews 2012) may reduce water-loss by decreasing the respiratory component of the water-loss rate. However, egg metabolism is affected most by temperature, than by water potential (Díaz-Paniagua and Cuadrado 2003, Andrews et al. 2008), and temperature was controlled in our experiments. 
Our results are best explained by invoking a mechanism to increase water-vapor pressure in the egg aggregation through the loss of water by individual eggs (Figure 3 ) thereby providing an environment in which eggs could absorb contributing to sorption, $m_{\mathrm{S}}$. Part of our model relies on the concept of uniform water gain over the entire egg surface, and water gain occurring at the same rate reported by Andrews et al. (2008) and Díaz-Paniagua et al. (1996) for lizards and tortoises, owing to the similarity in size and shape of the eggs of all three taxa. There is less increase in water-vapor pressure in small aggregations of eggs; thus, water-loss by gain is diminished or absent in intermediatesized aggregations. Moving air prevents the increase in water-vapor pressure in the aggregation; in the absence of available water for gain, the changes in mass are solely the result of loss $\left(m_{\mathrm{T}}\right)$. This explains why aggregated eggs in moving air experience a similar rate of water-loss to that of a non-aggregated isolated egg. When eggs are removed from moving air, water-vapor pressure increases in the aggregation to increase the availability of water for sorption $\left(m_{\mathrm{s}} \neq 0\right)$ and lower the rate of water-loss, thereby corroborating this mechanism. Although there are reports that water-conservation is enhanced by a moisturerich microclimate in egg clusters that is generated by the eggs themselves (Marco et al. 2004, Marco and Díaz-Paniagua 2008), this is the first direct evidence of its occurrence.

\section{Acknowledgments}

We thank Margaret Goodman (Department of Biology, Wittenberg University, Springfield, $\mathrm{OH}$, USA) for her helpful comments. Funding for this project and maintenance of snake cultures was provided by research grants from Wittenberg University. Richard Phillips holds permits for experimentation and husbandry care approved by IACUC (Wittenberg University, Springfield, $\mathrm{OH}, 2014)$.

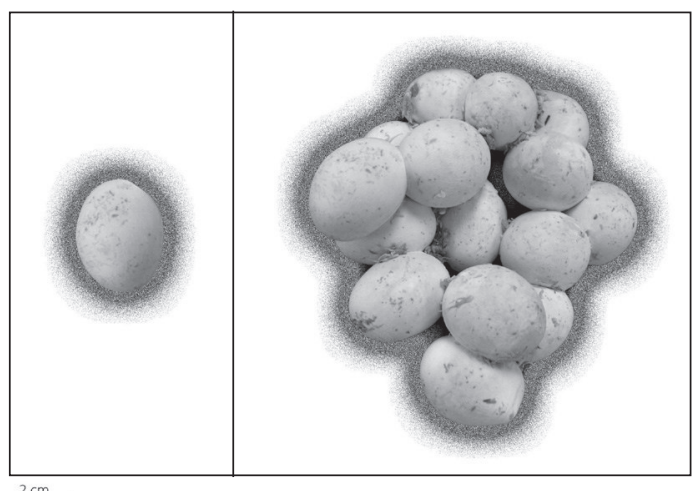

Figure 3. Proposed model for enhanced waterconservation within an egg clutch ( $L$. mexicana). Black halftone represents water molecules. In contrast to an isolated egg, the clutch has a larger water molecule gradient from which water absorption occurs that results in lower measureable water-loss by individual eggs. This effect disappears when the water molecule gradient is disrupted by exposing the egg clutch to moving air (Figure 2). Image credit: A. J. Jajack.

\section{References}

Andrews, R. M. 2012. Water vapor permeability of the rigidshelled gecko egg. Journal of Experimental Zoology Part A: Ecological Genetics and Physiology 317: 395-400.

Andrews, R. M., C. Díaz-Paniagua, A. Marco, and A. Portheault. 2008. Developmental arrest during embryonic development of the common chameleon (Chamaeleo chamaeleon) in Spain. Physiological and Biochemical Zoology 81: 336-344.

Arlian, L. G. and I. A. Eckstrand. 1975. Water balance in Drosophila pseudoobscura, and its ecological implications. Annals of the Entomological Society of America 68: 827-832.

Bryson Jr., R. W., J. Pastorini, F. T. Burbrink, and M. R. J. Forstner. 2007. A phylogeny of the Lampropeltis mexicana complex (Serpentes: Colubridae) based on mitochondrial DNA sequences suggests evidence for species-level polyphyly within Lampropeltis. Molecular Phylogenetics and Evolution 43: 674-684. 
Conant, R. and J. T. Collins. 1998. A Field Guide to Reptiles and Amphibians: Eastern and Central North America (Peterson Field Guides). 3rd edition. Boston. Houghton Mifflin Co. 616 pp.

Díaz-Paniagua, C., A. C. Andreu, and C. Keller. 2006. Effects of temperature on hatching success in field incubating nests of spur-thighed tortoises, Testudo graeca. Herpetological Journal 16: 249-257.

Díaz-Paniagua, C. and M. Cuadrado. 2003. Influence of incubation conditions on hatching success, embryo development and hatchling phenotypes of common chameleon (Chamaeleo chamaeleon) eggs. AmphibiaReptilia 24: 429-440.

Díaz-Paniagua, C., C. Keller, and A. C. Andreu. 1996. Clutch frequency, egg and clutch characteristics, and nesting activity of spur-thighed tortoises, Testudo graeca, in southwestern Spain. Canadian Journal of Zoology 74: 560-564.

Díaz-Paniagua, C., C. Keller, and A. C. Andreu. 1997. Hatching success, delay of emergence and hatchling biometry of the spur-thighed tortoise, Testudo graeca, in south-western Spain. Journal of Zoology 243: 543-553.

Gartska, W. R. 1982. Systematics of the mexicana species group of the colubrid genus Lampropeltis, with a hypothesis [of] mimicry. Breviora 466: 1-35.

Hadley, N. F. 1994. Water Relations of Terrestrial Arthropods. New York. Academic Press. 356 pp.

Keller, C., C. Díaz-Paniagua, and A. C. Andreu. 1997. Postemergent field activity and growth rates of hatchling spur-thighed tortoises, Testudo graeca. Canadian Journal of Zoology 75: 1089-1098.

Knülle, W. and T. L. Devine. 1972. Evidence for active and passive components of sorption of atmospheric water vapour by larvae of the tick Dermacentor variabilis. Journal of Insect Physiology 18: 1653-1664.

Lassiter, J. 2012. The kings of Mexico: care guide for the colorful Mexican kingsnakes. Reptiles Magazine 20: 46-51.

Liu, G., Y. Li, and A. K. Alva. 2012. Water potential vs. pressure in relation to water movement and transpiration in plants. International Journal of Agronomy and Plant Production 3: 369-373.

Marco, A. and C. Díaz-Paniagua. 2008. Aggregation protects flexible-shelled reptile eggs from severe hydric stress. Journal of Comparative Physiology B 178: 421-428.
Marco, A., C. Díaz-Paniagua, and J. Hidalgo-Vila. 2004. Influence of egg aggregation and soil moisture on incubation of flexible-shelled lacertid lizard eggs. Canadian Journal of Zoology 82: 60-65.

Miller, K., G. C. Packard, and M. J. Packard. 1987. Hydric conditions during incubation influence locomotor performance of hatchling snapping turtles. Journal of Experimental Biology 127: 401-412.

Plummer, M. V. and H. L. Snell. 1988. Nest site selection and water relations of eggs in the snake, Opheodrys aestivus. Copeia 1988: 58-64.

Sartori, M. R., E. W. Taylor, and A. S. Abe. 2012. Nitrogen excretion during embryonic development of the green iguana, Iguana iguana (Reptilia; Squamata). Journal of Comparative Biochemistry and Physiology A 163: 210-214.

Sokal, R. R. and F. J. Rohlf. 2012. Biometry: The Principles and Practice of Statistics in Biological Research. 4th edition. New York. W. H. Freeman. 937 pp.

Stahlschmidt, Z. R., T. C. M. Hoffman, and D. F. DeNardo. 2008. Postural shifts during egg-brooding and their impact on egg water balance in Children's pythons (Antaresia childreni). Ethology 114: 1113-1121.

Toolson, E. C. 1978. Diffusion of water through the arthropod cuticle: thermodynamic consideration of the transition phenomenon. Journal of Thermal Biology 3: 69-73.

Warton, D. I. and F. K. C. Hui. 2011. The arcsine is asinine: the analysis of proportions in ecology. Ecology 92: $3-10$.

Wharton, G. W. 1985. Water balance of insects. Pp. 565-603 in G. A. Kerkut and L. I. Gilbert (eds.), Comprehensive Insect Physiology, Biochemistry, and Pharmacology, Vol. 4. Oxford. Pergamon Press.

Wharton, G. W. and W. Knülle. 1966. A device for controlling temperature and relative humidity in small chambers. Annals of the Entomological Society of America 59: 627-630.

Winston, P. W. and D. S. Bates. 1960. Saturated solutions for the control of humidity in biological research. Ecology 41: 232-237. 